\title{
MORPHOLOGICAL AND CHEMICAL ANALYSIS OF ZIZYPHUS JUJUBA MILL. FRUITS FROM TIMIȘOARA BOTANICAL PARK
}

\author{
Daniela-Sabina Poșta ${ }^{1}$, Sándor Rózsa ${ }^{2 *}$, Tincuța-Marta Gocan ${ }^{2}$ \\ ${ }^{1}$ Banat University of Agricultural Sciences and Veterinary Medicine „King Michael I of Romania" from Timisoara, \\ Faculty of Horticulture and Forestry, 119 Aradului Street, 300645 Timisoara, Romania \\ ${ }^{2}$ University of Agricultural Sciences and Veterinary Medicine, \\ Faculty of Horticulture, 400372, 3-5 Mănăştur Street, Cluj-Napoca, Romania
}

Current Trends in

Natural Sciences

\begin{abstract}
Zizyphus jujuba Mill. belongs to the Rhamnales order, Rhamnaceae family, Rhamnus genus. The genus includes about 40 species native to tropical and subtropical regions of both hemispheres, as well as the Mediterranean region. Species Zizyphus jujuba Mill. it is native to SW Asia, has ornamental features and is found spontaneously on the Danube coast. The first cultivated varieties were introduced at the Faculty of Horticulture in Bucharest in Shanxi Province, China in a joint research project in 1997. In our study, the fruits were harvested from two genotypes in the Botanical Park of Timisoara. For the harvested fruits were analyzed: fruit weight $(\mathrm{g})$, seed weight ( $\mathrm{g})$, fruit length ( $\mathrm{mm})$, fruit width (mm) and chemical analyses were performed: soluble dry matter (\%), C vitamin (mg $\left.100 \mathrm{~g}^{-1}\right)$, total potassium content (mg $\left.100 \mathrm{~g}^{-1}\right)$ and protein (\%). In the analyzed fruits, the soluble dry matter varied between $28.3-29.81 \%$, C vitamin between

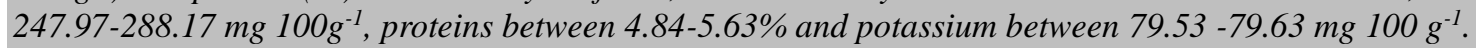

Keywords: Chinese date palm, chemical analysis, morphological characters, Zizyphus jujuba Mill.

\section{INTRODUCTION}

Zizyphus jujuba Mill. - Chinese date, belongs to the order Rhamnales, family Rhamnaceae, genus Rhamnus (Săvulescu et al., 1958).

The genus includes about 40 species native to the tropical and subtropical regions of both hemispheres, as well as the Mediterranean region. The species Zizyphus jujuba Mill., reaches a height of $8 \mathrm{~m}$, most often considered a shrub than a tree, is native to SW Asia, has ornamental features and is found spontaneously on the Danube coast, between Hîrșova and Dealul Celea Mare as well between Măcin and Cerna (Dumitriu-Tătăranu et al., 1960).

The Roman emperor Octavian Augustus brought the Chinese date from Syria to Italy and then spread to other Mediterranean countries including Dobrogea, in the region between the Danube and the Black Sea (Ciocârlan, 2000).

The locals called the fruits of this species "Dobrogea olive". In the Dobrogea area, two genotypes of jujube were identified, one in Jurilovca and another in Ostrov. Within the 'Jurilovca' population, two jujube biotypes were identified: 'Jurilovca 1' and 'Jurilovca 2'. Romanian jujube genotypes produce small fruits, but have adapted to local climate and soil conditions over the centuries. 'Jurilovca' biotypes could be interesting for future use as rootstocks (Stanica, 2009). 


\begin{tabular}{l}
\hline $\begin{array}{c}\text { Current Trends in Natural Sciences } \\
\text { Vol. 10, Issue 19, pp. 328-332, 2021 } \\
\text { https://doi.org/10.47068/ctns.2021.v10i19.042 }\end{array}$ \\
$\begin{array}{l}\text { Current Trends in Natural Sciences (CD-Rom) } \\
\text { Current Trends in Natural Sciences (on-line) }\end{array}$ \\
$\begin{array}{l}\text { ISSN: 2284-953X } \\
\text { ISSN-L: 2284-9521 }\end{array}$ \\
ISSN-L: 2284-9521 \\
\hline
\end{tabular}

In China, jujubes are popularly called "Chinese date" or "red date" and are eaten fresh, dried, smoked, candied, pickled, baked in pies, or boiled in rice (Small, 2012).

Ziziphus jujuba Mill., the Chinese date, comes from the middle and lower part of the Yellow River, the "mother river" of the Chinese people. This species is widespread in at least 48 countries on all continents except Antarctica and is becoming increasingly important, especially in arid and semiarid marginal lands. Based on a systematic analysis of the unique characteristics of jujube, we suggest that it deserves to be recognized as a superfruit (Mengjun Liu, et al. 2020). In 1996, the collaboration between the Faculty of Horticulture in Bucharest and the Agricultural Academy in Shanxi Province, China began in a joint research project starting from the Ziziphus jujuba Mill species. (Stănica, 2019 a).

Jujube fruits are rich in bioactive compounds and can be introduced into the healthy diet of humans (Cosmulescu, 2018 a).

\section{MATERIALS AND METHODS}

The study was conducted by analyzing the fruits of two ornamental shrubs of Ziziphus jujuba Mill. identified in the Botanical Park from Timisoara, introduced according to the archive from the discipline of Botany on February 19, 1987 following the donation of the Dumitrescu family. The fruits were harvested at the end of October 2019. Two ornamental shrubs were selected from the total population, depending on the degree of fruiting and the size of the fruits (figure 1).
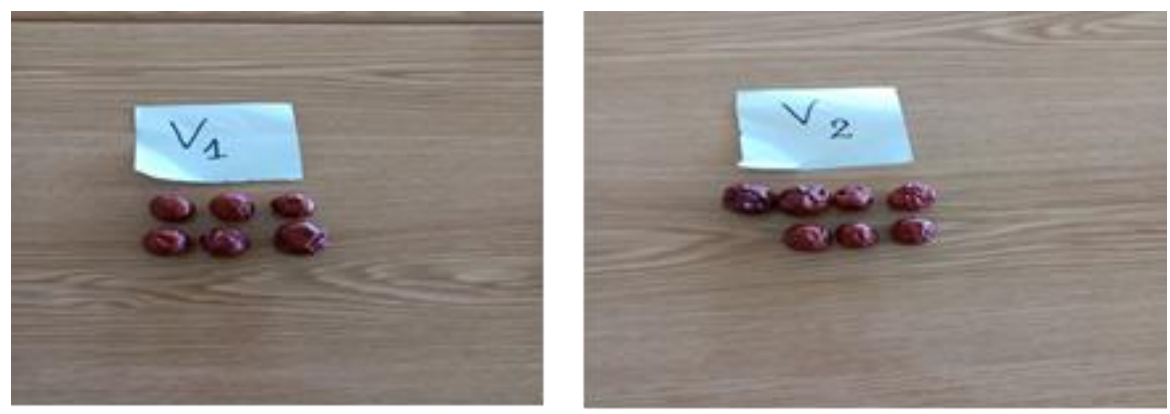

Figure 1. Ziziphus jujuba Mill fruits experimental variants

For the harvested fruits were analyzed: fruit weight $(\mathrm{g})$, seed weight $(\mathrm{g})$, fruit length $(\mathrm{mm})$, fruit width $(\mathrm{mm})$ and chemical analyses were performed: soluble dry matter $(\%), \mathrm{C}$ vitamin $\left(\mathrm{mg} 100 \mathrm{~g} \mathrm{~g}^{-1}\right)$,

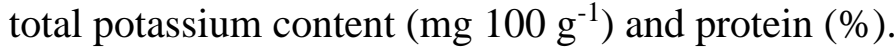

\section{RESULTS AND DISCUSSIONS}

Table 1 presents the results of the morphological characters of the fruits from the two shrubs in the Botanical Park of Timișoara.

These can be compared with the results obtained by the team from the Faculty of Horticulture within USAMV Bucharest on the weight of fruits from local populations of Romanian jujube (Stanica, $2019 \mathrm{~b}$ ), namely the weight of the fruits varied from $0.96 \mathrm{~g}$ (sour jujube Chinese) up to $1.35 \mathrm{~g}$ (Jurilovca population 2).

The weight of the fruits of the Ostrov biotype was $6.29 \mathrm{~g}$. 
Current Trends in Natural Sciences

Vol. 10, Issue 19, pp. 328-332, 2021

https://doi.org/10.47068/ctns.2021.v10i19.042

Current Trends in Natural Sciences (on-line)

Table 1. Morphological characters of Ziziphus jujuba Mill. fruits

\begin{tabular}{|c|c|c|c|c|}
\hline $\begin{array}{c}\text { Experimental } \\
\text { variant }\end{array}$ & $\begin{array}{c}\text { Fruit } \\
\text { length } \\
(\mathrm{mm})\end{array}$ & $\begin{array}{c}\text { Fruit } \\
\text { width } \\
(\mathrm{mm})\end{array}$ & $\begin{array}{c}\text { Fruit } \\
\text { weight } \\
(\mathrm{g})\end{array}$ & $\begin{array}{c}\text { Seed } \\
\text { weight } \\
(\mathrm{g})\end{array}$ \\
\hline $\mathrm{V} 1$ & 19.24 & 18.13 & 5.47 & 0.31 \\
\hline $\mathrm{V} 2$ & 22.68 & 21.82 & 6.13 & 0.43 \\
\hline Average & 20.96 & 19.97 & 5.80 & 0.37 \\
\hline
\end{tabular}

Data on the soluble dry matter content of the Ziziphus jujuba Mill. Are given in Table 2.

Table 2. Unilateral influence of soluble dry matter content

\begin{tabular}{|c|c|c|c|c|}
\hline \multirow{2}{*}{$\begin{array}{c}\text { Experimental } \\
\text { variant }\end{array}$} & Soluble dry matter content $\%$ & \multirow{2}{*}{ Difference $\pm \mathrm{D}$} & $\begin{array}{c}\text { Signification of } \\
\text { difference }\end{array}$ \\
\cline { 2 - 3 } & Obtained values & $\%$ & -0.75 & 00 \\
\hline V1 & 28.31 & 97.4 & 0.75 & $* *$ \\
\hline V2 & 29.81 & 102.6 & 0.00 & Control \\
\hline Average & 29.06 & 100.0 & 16.38 \\
\\
\multicolumn{2}{|c}{} & 37.82 & \\
& LSD (p 5\%) $(\mathrm{p} 1 \%)$ & 120.94 &
\end{tabular}

Following the presented data, it is noticed that the V2 experimental variant registers a higher top content $(29.81 \%)$ of soluble dry matter, with a difference of $0.75 \%$ being significantly different from the average of the experience considered as a control. The values obtained are comparable with those obtained by Cosmulescu et al. (2018 b).

Table 3 presents the data on the $\mathrm{C}$ vitamin content of the experimental variants.

Table 3. Unilateral influence of C vitamin content

\begin{tabular}{|c|c|c|c|c|}
\hline \multirow{2}{*}{$\begin{array}{c}\text { Experimental } \\
\text { variant }\end{array}$} & \multicolumn{2}{|c|}{$C$ vitamin $(\mathrm{mg} / \mathrm{lo0g})$} & \multirow{2}{*}{ Difference $\pm \mathrm{D}$} & \multirow{2}{*}{$\begin{array}{c}\text { Signification of } \\
\text { difference }\end{array}$} \\
\hline & Obtained values & $\%$ & & \\
\hline V1 & 247.97 & 92.5 & -20.10 & 0 \\
\hline $\mathrm{V} 2$ & 288.17 & 107.5 & 20.10 & $*$ \\
\hline Average & 268.07 & 100.0 & 0.00 & Control \\
\hline & $\begin{array}{l}55 \%) \\
1 \%) \\
0.1 \%)\end{array}$ & & $\begin{array}{l}0.19 \\
0.45 \\
1.42\end{array}$ & \\
\hline
\end{tabular}

Regarding the amount of $\mathrm{C}$ vitamin content of experimental variants, it can be seen that the fruits of shrub 2 have a higher content of $C$ vitamin, with a difference of $20.1 \%$ from the average, considered as control, being significantly positive and the content of $\mathrm{C}$ vitamin for the shrub 1 fruits being significantly negative compared to the same control. The values obtained are in line with those reported by Gao et al., (2013) and Cosmulescu et al. (2018 a).

Table 4 presents the data on the protein content of the experimental variants.

Table 4. Unilateral influence of protein content

\begin{tabular}{|c|c|c|c|c|}
\hline \multirow{2}{*}{$\begin{array}{c}\text { Experimental } \\
\text { variant }\end{array}$} & Obtained values & $\%$ & Difference $\pm \mathrm{D}$ & $\begin{array}{c}\text { Signification of } \\
\text { difference }\end{array}$ \\
\cline { 2 - 3 } & 4.84 & 87.8 & -0.39 & - \\
\hline V1 & 5.63 & 112.2 & 0.40 & Control \\
\hline V2 & 5.24 & 100.0 & 0.00 & \\
\hline Average & LSD (p 5\%) & 0.58 & 1.34 \\
\\
LSD (p 1\%) \\
LSD (p 0.1\%)
\end{tabular}


Following the data on the unilateral influence of the protein content of the fruits of the two studied shrubs, the values obtained were $4.84 \%$ for the fruits of shrub 1 and $5.63 \%$ for the fruits of shrub 2 , but these are not statistically assured. These results are close to those obtained by Li et al. (2007). Table 5 presents the data on the potassium content of the experimental variants.

Table 5. Unilateral influence of potassium content

\begin{tabular}{|c|c|c|c|c|}
\hline \multirow{2}{*}{$\begin{array}{c}\text { Experimental } \\
\text { variant }\end{array}$} & Obtained values & $\%$ & \multirow{2}{*}{ Difference $\pm \mathrm{D}$} & $\begin{array}{c}\text { Signification of } \\
\text { difference }\end{array}$ \\
\cline { 2 - 3 } & 79.63 & 108.7 & 0.05 & $*$ \\
\hline V1 & 79.53 & 91.3 & -0.05 & 0 \\
\hline V2 & 79.58 & 100.0 & 0.00 & Control \\
\hline Average & LSD (p 5\%) & 0.58 & \\
& LSD (p 1\%) \\
LSD (p 0.1\%) & 4.34 & \\
\end{tabular}

The values obtained regarding the potassium content register the best value $(79.63 \mathrm{mg} / 100 \mathrm{~g})$ for shrub 1 with a difference of $0.05 \%$ being significantly positive, compared to the average considered as a control. Regardless of the fruits analyzed, the values obtained are in line with those reported by Pareek, (2013).

\section{CONCLUSIONS}

Following the results of the study of morphological characters and chemical analyzes of jujube fruits from the Botanical Park shrubs, it can be concluded that they come from local populations found in Dobrogea.

Due to the high content of $\mathrm{C}$ vitamin, the content of potassium, protein, dry matter, in the Botanical Park jujube fruits, these can be recommended for visitors' consumption.

\section{REFERENCES}

Ciocârlan, V. (2000). Flora ilustrată a României [Illustrated Flora of Romania]. Pterydophyta et Spermatophyta. Editura Ceres, Bucureşti.

Cosmulescu, S., Trandafir, I., Nour, V., Achim, G., Botu, M., Iordanescu, O. (2018 a). Variation of Bioactive Compounds and Antioxidant Activity of Jujube (Ziziphus jujuba) Fruits at Different Stages of Ripening. Notulae Botanicae Horti Agrobotanici Cluj-Napoca, 46(1), 134-137. https://doi.org/10.15835/nbha46110752

Cosmulescu, S., Trandafir, I., Nour, V., Achim, G., Botu, M., Iordanescu, O. (2018 b). Variation of Bioactive Compounds and Antioxidant Activity of Jujube (Ziziphus jujuba) Fruits at Different Stages of Ripening. Notulae Botanicae Horti Agrobotanici Cluj-Napoca, 46(1), 134-137. https://doi.org/10.15835/nbha46110752

Dumitriu-Tătăranu, I., Pașcovschi, S., Beldie, AL., Spîrchez, ST., Radu., Hulea, A., Clonaru, Al., Ocskay, S. (1960). Arbori și arbuști forestieri și ornamentali cultivați în RPR [Forest and ornamental trees and shrubs grown in the $R P R]$, Editura Agro-silvică, București.

Gao, Q.H., Wu, C.S., Wang, M. (2013). The jujube (Ziziphus jujuba Mill.) fruit: a review of current knowledge of fruit composition and health benefits. Journal of Agricultural and Food Chemistry 61(14), 3351-3363.

Li, M., G.L., Yang, S., Min, X.Y., Gao, Y., Wang, M., Li, R. (2007). Extract process of cyclic adenosinem on ophoshate (cAMP) in Ziziphus jujube. J. Chinese Med. Mater. 30, 1143-1145.

Mengjun, L., Jiurui, W., Wang, L., Liu, P., Zhao,J., Zhao, Z., Yao, Z., Stănică, F., Liu, Z., Wang, L., Ao, C., Dai, L., Li, X., Zhao X., Jia, C. (2020). The historical and current research progress on jujube a superfruit for the future. Horticulture Research volume 7, Article number: 119.

Pareek, S. (2013). Nutritional composition of jujube fruit. Emirates Journal of Food and Agriculture, 463-470.

Săvulescu, T., Beldie, Al., Grințescu, I., Gușuleac, M., Morariu, I., Nyárády A., Acad. Nyárády, E.I., Paucă, A., Răvăruț, M., Șerbănescu, I., Todor, I., Țopa, M. (1958). Flora Republicii Populare Române [Flora of the Romanian People's Republic]. Editura Academiei Republicii Populare Române.

Small, E. (2012). TOP 100 Exotic Food Plants. CRC Press. Taylor \& Francis Group. 


\section{Current Trends in Natural Sciences}

Vol. 10, Issue 19, pp. 328-332, 2021

https://doi.org/10.47068/ctns.2021.v10i19.042

Current Trends in Natural Sciences (on-line)

ISSN: 2284-953X

Current Trends in Natural Sciences (CD-Rom)

ISSN-L: 2284-9521

ISSN: 2284-9521

ISSN-L: 2284-9521

Stanilă, A. (2013) Analiza compuşilor bioactivi din alimente [Analysis of bioactive compounds in food], Ed. AcademicPres, Cluj-Napoca, ISBN-978-973-744-318-2.

Stănică, F. (2009 a) Characterization of two romanian local biotypes of ziziphus jujube. Acta Hortic. 840, 259-262 https://doi.org/10.17660/ActaHortic.2009.840.34

Stănică, F. (2019 b) Twenty years of jujube (Ziziphus jujuba mill.) Research in Romania, Scientific Papers. Series B, Horticulture. Vol. LXIII, No. 2, Print ISSN 2285-5653, p. 17-23. 